\title{
Shallow seismic reflectors and upper Quaternary sea level changes in the Ubatuba region, São Paulo State, Southeastern Brazil*
}

\author{
Michel Michaelovitch de Mahiques ${ }^{1 * *}$ \& Luis Antonio Pereira de Souza ${ }^{2}$ \\ ${ }^{1}$ Instituto Oceanográfico da Universidade de São Paulo \\ (Caixa Postal 66149, 05315-970 São Paulo, SP, Brasil) \\ ${ }^{2}$ Instituto de Pesquisas Tecnológicas de São Paulo \\ Divisão de Geologia \\ (05508-901 São Paulo, SP, Brasil)
}

- Abstract The relationship between shallow seismic units and Quaternary sea level changes in Southeastern Brazil is based on boomer profiles and core data from the Ubatuba region, northern São Paulo coast. In Flamengo and Palmas bays, the interpretation of seismic lines revealed the occurrence of four sedimentary units, separated by regionally correlated reflectors. The upper two units correspond to Late Pleistocene and Holocene deposits. The lowermost sedimentary units were correlated to the older Quaternary transgressive events. These deposits, which have not yet been described for this area, can presently be found on the Rio Grande do Sul coastal plain. In the Boqueirão Strait, two erosional events in the sedimentary strata have been associated with the Cananéia (maximum at 120,000 yr. B.P.) and Santos (maximum at 5,100 yr. B.P.) sea-level rise events.

- Resumo: A partir de registros sísmicos, obtidos por "boomer" e dados de um testemunho, foi estabelecida uma relação entre unidades sísmicas rasas e variações relativas do nível do mar no Quaternário, na região de Ubatuba, litoral norte do Estado de São Paulo. A interpretação das linhas sísmicas revelou a ocorrência de quatro unidades sísmicas, associadas a sequêências sedimentares, separadas por refletores sísmicos de expressão regional. As duas unidades superiores correspondem a depósitos do Pleistoceno Superior e Holoceno, e encontram correspondência em outras áreas do planeta. Na região do Boqueirão, dois eventos erosivos são associados com os últimos eventos de subida do nível do mar. As unidades sedimentares inferiores são correlacionáveis a eventos transgressivos mais antigos, que não haviam sido ainda referidos para a área.

- Descriptors: Reflection seismics, Coastal region, Sea-level changes, Ubatuba, São Paulo.

- Descritores: Sísmica de reflexão, Região costeira, Variações do nível do mar, Ubatuba, São Paulo.

\section{Introduction}

In Southeastern Brazil, at least two Quaternary sea level rise events can be recognised in the coastal region. One, named Cananéia, presented

(*) Supported by the Fundação de Amparo à Pesquisa do Estado de São Paulo (FAPESP) - Processo 88/0109-9 and 89/2159-2.

(**) Researcher CNPq - Brazil

Contr. no. 821 do Inst. oceanogr. da Usp. its maximum at approximately $120,000 \mathrm{yr}$. BP and reached a maximum of $8.0 \mathrm{~m}$ above the present sea level. The other, named Santos, had its maximum at $5,100 \mathrm{yr}$. BP and reached a maximum of $5.0 \mathrm{~m}$ above the present sea level (Suguio \& Martin 1978). These events were separated by a regressive event, correlated to the Würm-Wisconsin (maximum at 18,000-yr. BP), when the sea level dropped approximately 130 meters below the level present on the Southeastern Brazilian margin (Kowsmann \& Costa, 1974; 1979). On the Southeastern Brazilian 
coastal plains, despite the existence of several Quaternary sea-level curves that are based on shellmidden ("sambaquis") and Vermetidae positions, especially for the last 7,000 years (Suguio et al., 1982; Martin et al., 1985), little information is available on the buried deposits of coastal submerged areas. This lack of data makes it difficult to establish the sedimentary evolution models for the Quaternary. For this reason, the study of the Holocene sedimentary sequences in enclosed embayments may provide a more reliable set of information on the evolution of the coastal area (Mahiques, 1992; Silva \& Baptista Neto, 1992*). In a restricted area of the northern coast of São Paulo State, seismic sequences may be recognised that can be correlated to relative sea level change events and interpreted in terms of models of Quaternary coastal change.

\section{Study area}

The study area comprises Flamengo and Palmas bays, two small and shallow $(0-20 \mathrm{~m})$ semienclosed marine environments, that are connected by a strait, $35 \mathrm{~m}$ deep and $500 \mathrm{~m}$ wide, called Boqueirão da Ilha Anchieta (Fig. 1).

Precambrian high-rank metamorphic rocks of the Complexo Costeiro unit and granitic bodies that form the Serra do Mar mountain chain dominate the northern coast of São Paulo State. Between the projections of the crystalline rocks into the sea there are small Quaternary coastal plains. Small rivers form the fluvial system with a dendritic to subparallel drainage pattern (SICCT, 1981).

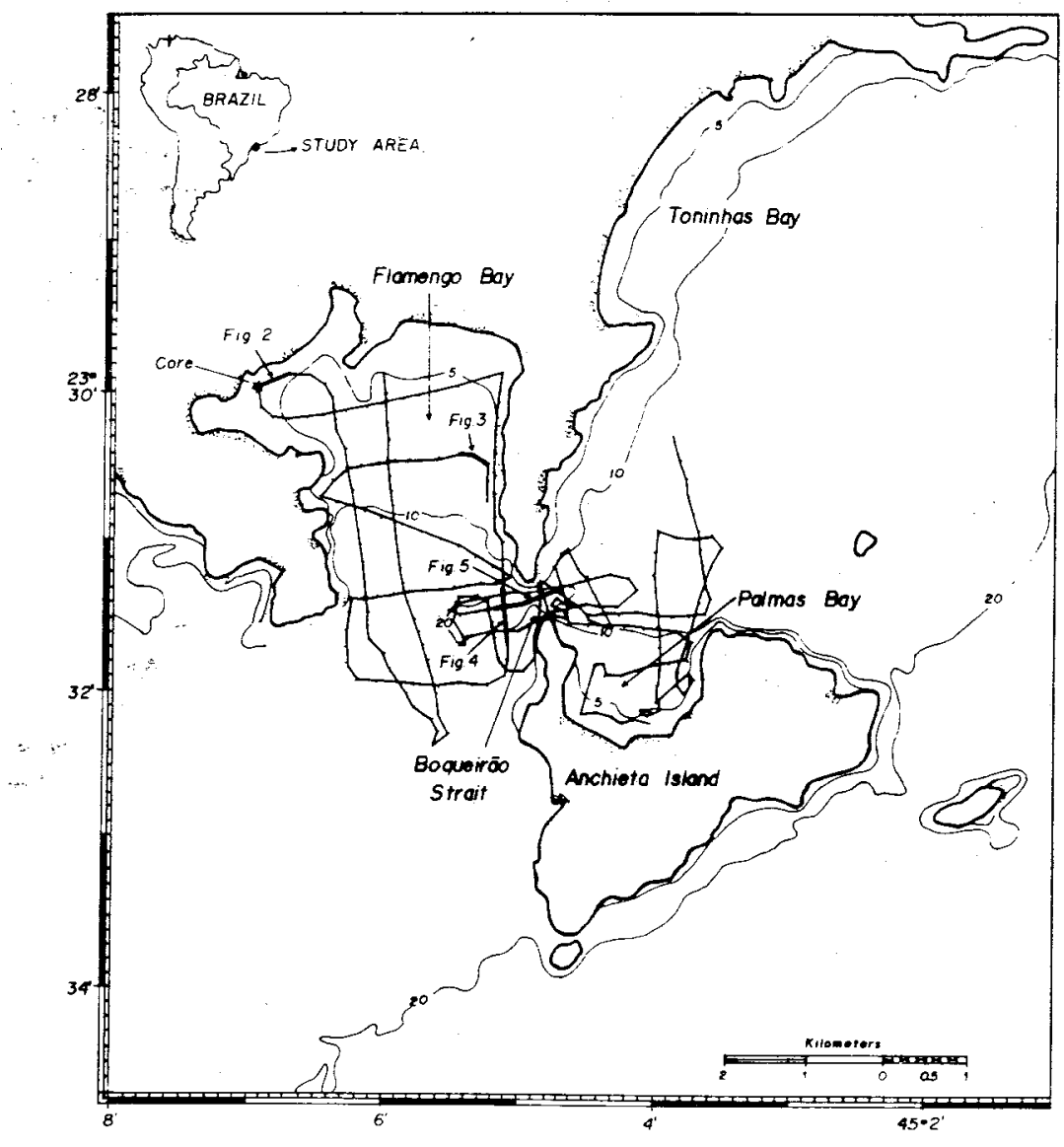

Fig. 1. Location of the study area (bathymetric lines in meters), position of the core collected in Flamengo Bay and seismic survey grid showing location of figures 2 to 5 .

(*) Silva, M. A. M. \& Baptista Neto, J. A. 1992. Caracterização do tômbolo da Praia de Charitas - Enseada de Jurujuba (Baía de Guanabara). In: CONGRESSO BRASILEIRO DE GEOLOGIA, 37. São Paulo, 1992. Resumos Expandidos. São Paulo, SBG, $1: 96-97$
The distribution of the surface sediments is determined by the shape and size of the embayments and by the rainfall regime. The rainfall regime in particular controls the input of terrigenous sediments, leading to the deposition of silts and very-fine sands, 
rich in organic carbon (up to $2.5 \% \mathrm{C}_{\mathrm{org}}$ ) and poor in calcium carbonate (commonly less than $30 \% \mathrm{CaCO}_{3}$ ) (Mahiques, 1995).

In Flamengo Bay, the sediments are transported by a clockwise circulation system, which begins with the entrance of oceanic water along the westernmost part of the bay's mouth. SW- NE or NESW wave-driven current velocities can increase during the passage through the Boqueirão Strait (Magliocca \& Kutner, 1965) and deviate the water flow, in the easternmost part of the bay.

The Boqueirão Strait is one of the several coastal depressions present on the southeastern coast of Brazil. The origin of Boqueirão Strait is probably related to the ancient drainage systems that developed during the upper Quaternary low sea level periods (Almeida, 1964), associated to tectonic structures. On the other hand its evolution may have been associated to the erosion by tidal currents during the Santos sea level rise event (Mahiques et al., 1989*).

The circulation in the Boqueirão Strait as well as that in Palmas Bay is strongly dependent on wave action and wind-driven currents, which are determined by the atmospheric conditions in the Southeastern region of Brazil (Tessler, 1988). In general, the passage of cold fronts leads to the generation of strong SW - NE currents that reach up to $80 \mathrm{~cm} / \mathrm{sec}$ in the Boqueirão area. In normal situations, NE - SW currents prevail there.

\section{Seismic Survey and coring}

Approximately $56.8 \mathrm{~km}$ of seismic profiles (Fig. 1) were collected on board the R/V. "Albacora" of the Instituto Oceanográfico of the Universidade de São Paulo. The seismic source was a HUNTEC Hydrossonde M2-A, from the Instituto de Pesquisas Tecnológicas do Estado de São Paulo. The sound source utilised a band frequency between 900 and $9500 \mathrm{~Hz}$ (with a peak at $5000 \mathrm{~Hz}$ ) and an energy output of about 150 joules per pulse.

Navigational control was provided by a GEOTRON BT-100 Minirange system, from the Banco de Equipamentos Geofisicos do Programa de Geologia e Geofisica Marinha (BEG-PGGM). Relative positions were obtained every 2 minutes, at a speed of approximately 3 knots.

A $490-\mathrm{cm}$ long vibracore was collected from the inner part of Flamengo Bay (Fig. 1), in order to obtain dating material and to identify the lithologies of the uppermost sedimentary column. Mollusc shells, found in living position were dated by $\mathrm{C} 14$

(*) Mahiques, M. M; Furtado, V. V. \& Tessler, M. G. 1989. Origin and evolution of isolated depressions on the coastal region of São Paulo and Rio de Janeiro states. In: INTERNATIONAL SYMPOSIUM ON GLOBAL CHANGES IN SOUTH AMERICA DURING THE QUATERNARY: PAST-PRESENTFUTURE. São Paulo, 1989. Abstracts. São Paulo, ABEQUAINQUA, 1:285-288.
(AMS technique) by the Beta Analytic Laboratories (USA).

\section{Results}

The analysis of seismic profiles reveals the existence of four units, separated by three regionally correlated reflectors. Figure 2 shows a complete succession of sedimentary units found in the area.

The reflector $\mathrm{R} 1$ defines the uppermost sequence (Unit U1). It is fairly flat and it exhibits conspicuous changes in internal reflection pattern, running parallel in the outer part of the bay and being transparent in the inner part. In most of Boqueirão area $\mathrm{U} 1$ as well as deeper units are completely eroded.

The second unit (Unit U2) overlies an irregular erosive reflector (R2). Cut-and-fill, chaotic structures and dipping internal reflectors (Fig. 3) characterise the basal part of the unit. Its topmost part is mainly characterised by transparent and parallel reflection patterns. In the inner parts of the bay, R2 and R3 onlap the acoustic basement.

Reflector R3 separates the deepest sedimentary units (U3 and U4) and its non erosive shape characterises it. Unit U3 and the uppermost sequence of $U 4$ present a high variability of internal reflection patterns.

The seismic records of Boqueirão Strait (Figs 4 and 5) reveal two features of erosional truncations. The first feature corresponds to reflector $\mathrm{R} 3$ that has a high reflection coefficient, and cuts across two units of deeper sedimentary units (Fig. 4). Reflectors R1 and R2 are truncated by the present surface. One important characteristic related to this feature is that the deepest portion of the Boqueirão Strait presents a conspicuous depositional sequence, indicated by a divergent fill facies. On the other hand, the flanks of the Boqueirão are clearly erosional.

The whole sedimentary section overlies the acoustic basement formed by the granitic and gneissic rocks of the Complexo Costeiro, which is very irregular and presents high relief.

The core collected in the inner part of Flamengo Bay (Fig. 6) presents a sharp contact, situated at $360 \mathrm{~cm}$ depth, which separates an uppermost dark grey sandy mud lithofacies, rich in organic carbon (up to $20 \mathrm{mg} / \mathrm{g}$ org C), and with variable amounts of plant debris and calcium carbonate, from lowermost light grey quartzose sand facies, very poor in organic carbon and calcium carbonate. These basal sediments present bioturbations as a major sedimentary structure. These structures are very similar to that described by Rodrigues et al. (1984), as formed by Callichirus major, which is a very common crustacean that lives in the inter-tidal zone of sandy shores. 

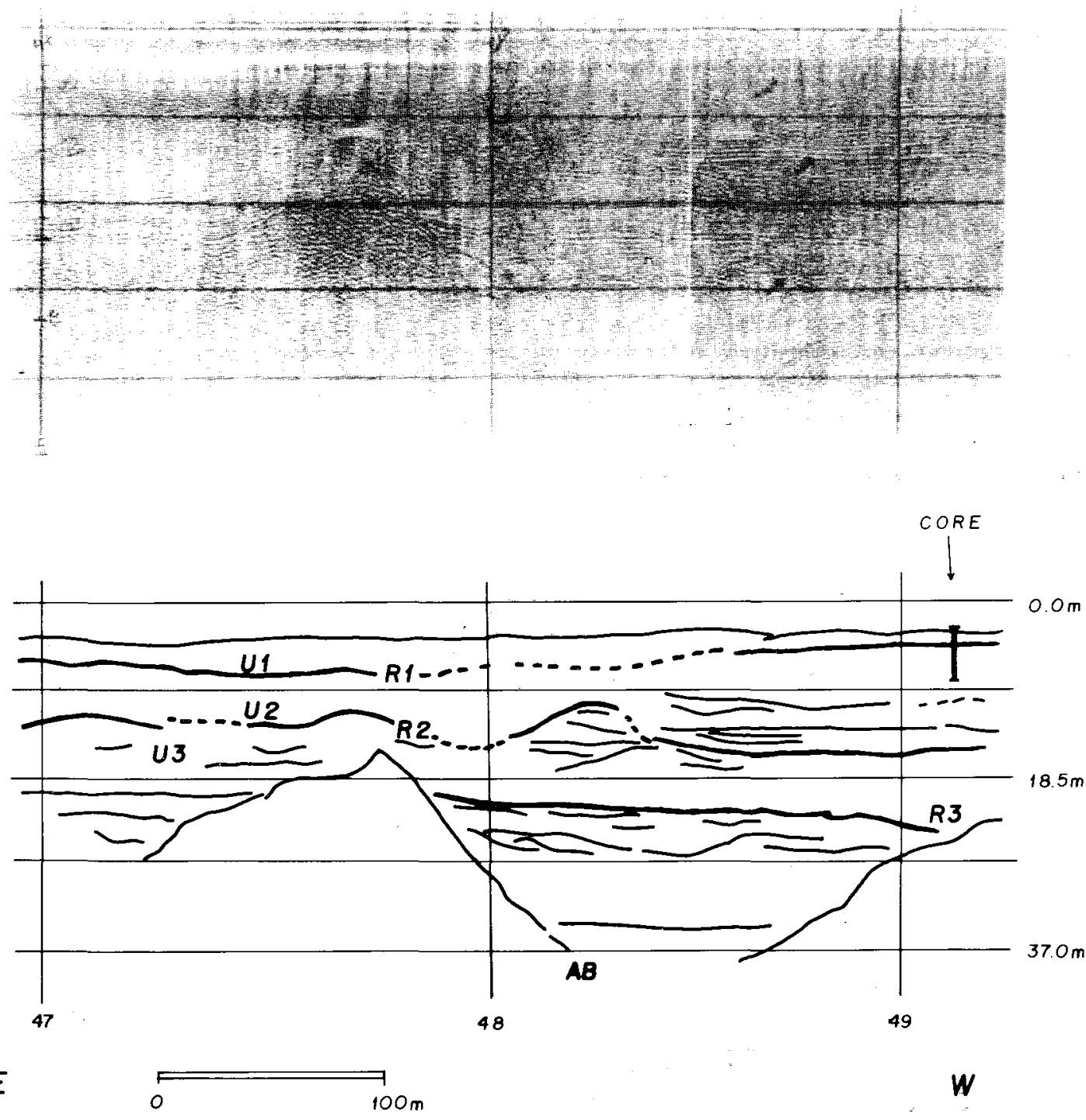

145

Fig. 2. a) Seismic line and, b) Interpretation of the complete section of seismic sequences and reflectors, found in the northwesternmost part of Flamengo Bay.

A C14 dating provided an age of $7470 \pm 60$ yr. BP for a shell collected immediately below the contact between the two lithofacies.

\section{Discussion}

Reflector R1 can be easily correlated to the sharp mud-sand contact found in the core, which was collected in the northwesternmost part of Flamengo Bay. The lower sequence observed in this core is of quartzose sandy strata, with Callichirus major tubes, but poor in bioclastic compounds. According to Duleba (1993) this sand sequence is almost sterile in terms of foraminifer content and was interpreted as being a beach deposit. The upper sequence, which corresponds to Unit $U 1$, is composed of marine muddy-sand sediments, with variable amounts of shell fragments and plant debris, rich in organic carbon, that are representative of the low energy conditions that prevail presently in the area. Foraminiferal data show a progressive increase of density and diversity up to the intermediate part of the upper sequence (Duleba, 1993), leading to a correspondence of the basal part of Unit U1 to the submergence Phase I described by Dominguez \& Wanless (1991) in the Doce River coastal deposits. Thus, sediments of Unit U1 correspond to the holocenic marine sedimentation of the area, which could have started at approximately 7,500 yr. BP.

Reflector R2 could be interpreted as an erosional surface developed after the maximum of the Cananéia Transgression up to the time of the maximum late Pleistocene regression, which occurred at 18,000 yr. B.P. Thus, Unit U2 probably corresponds to late Pleistocene alluvial and coastal plain sediments developed during isotopic stages 4 to 

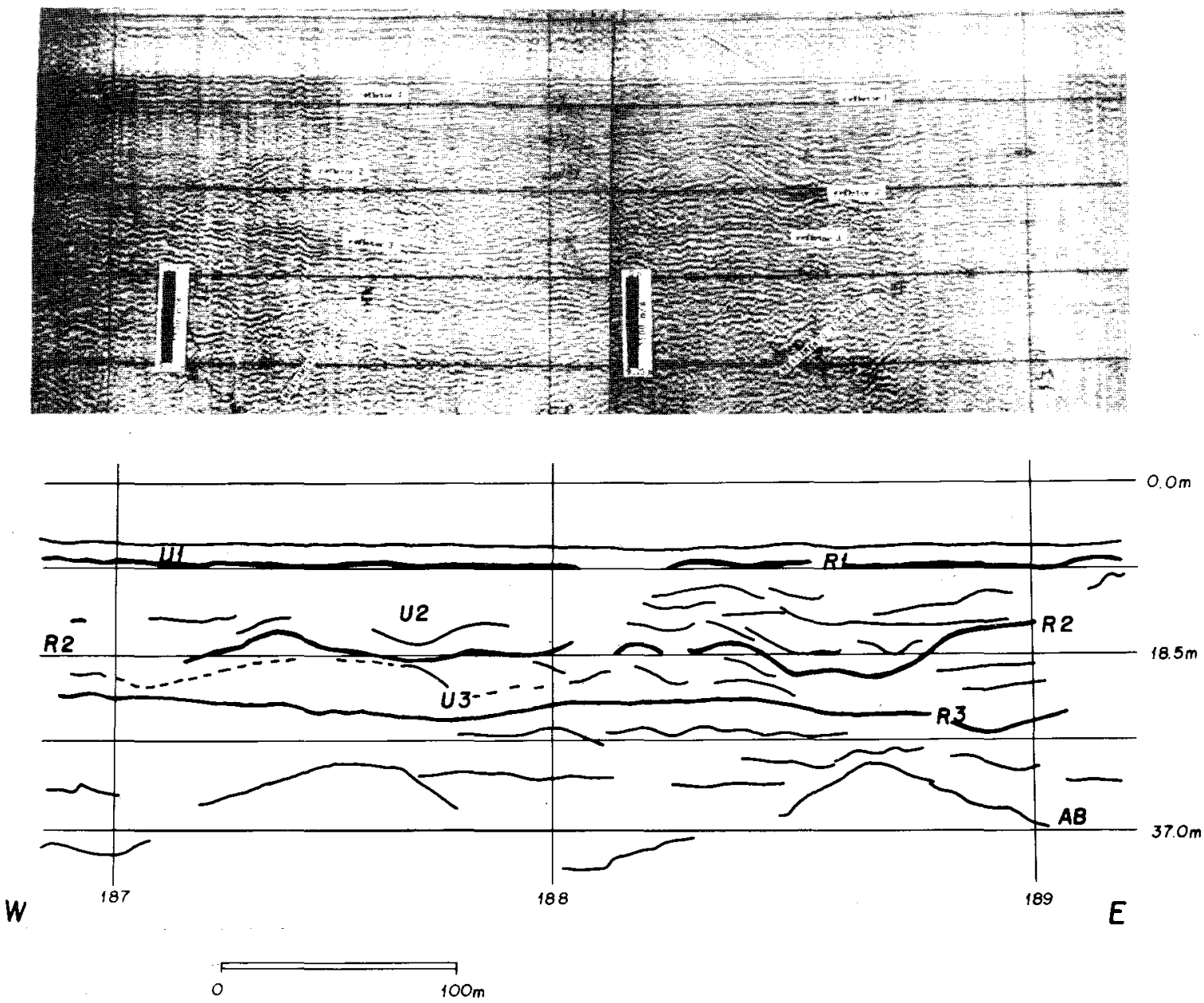

Fig. 3. a) Seismic line and, b) Interpretation of the complete section of seismic sequences and reflectors, found in the easternmost part of Flamengo Bay.

2 (Inman, 1983; Johnson, 1983; Ronen, 1983; Giresse, 1989).

Units U1 and U2 can be correlated respectively the upper Holocene and uppermost Pleistocene units already described worldwide (Saito, 1989; Bodur \& Ergin, 1992; Marsset et al., 1996).

According to the evolutionary model, proposed by Suguio \& Martin (1978), for the coast of the State of São Paulo, we can interpret units U3 and $\mathrm{U} 4$ as representing the Pleistocene sequence correlated to the Cananéia deposits or even to older sequences. R3 could represent either an erosional surface, as an abrupt change in the sedimentation pattern, as for R1.

The analysis of Boqueirão Strait profiles reveals the occurrence of two important erosional events, indicated by the shape of the present bottom surface and by reflector $\mathrm{R} 3$. The reflector $\mathrm{R} 3$ shows a pattern that is similar to the present surface bottom. Thus, we may assume that the bottom dynamic processes that were responsible for the development of R3 were the same as those, which maintain the bottom shape of the Boqueirão as it is at present. Admitting that the scour of the Boqueirão is correlated to high sea level, we can assume that R3 was developed during a high sea level period, possibly correlated to the maximum of the Cananeia event (ca. 120,000 yr. B.P.), when the sea level reached up to 8 meters above the present sea level.

Despite their absence from the emerged coastal deposits, at least two sedimentary units can be identified below reflector R3 (U4 and underlying deposits) and above the acoustic basement. Assuming that U4 corresponds to the transgressive deposits correlated to the Cananéia event, we can associate the lowermost sedimentary sequences to older transgressive-regressive deposits. In the Rio Grande do Sul coastal plain (southward of the study area), two other Pleistocene sedimentary sequences are found (Long et al., 1989*), which were associated with isotopic stages 8 and 10 or 6 and 8 . Thus, we may correlate the lowermost deposits of the study area to one of these sequences.

(*) Long, T.; Tastet, J. P.; Asmus, H. E. \& Klingebiel, A. 1989. Sedimentary evidences of coastal evolution in south Brazil during the last 400,000 (?) years. In: INTERNATIONAL SYMPOSIUM ON GLOBAL CHANGES IN SOUTH AMERICA DURING THE QUATERNARY: PAST-PRESENTFUTURE. São Paulo, 1989. Abstracts. São Paulo, ABEQUA/INQUA, 1:241-244. 


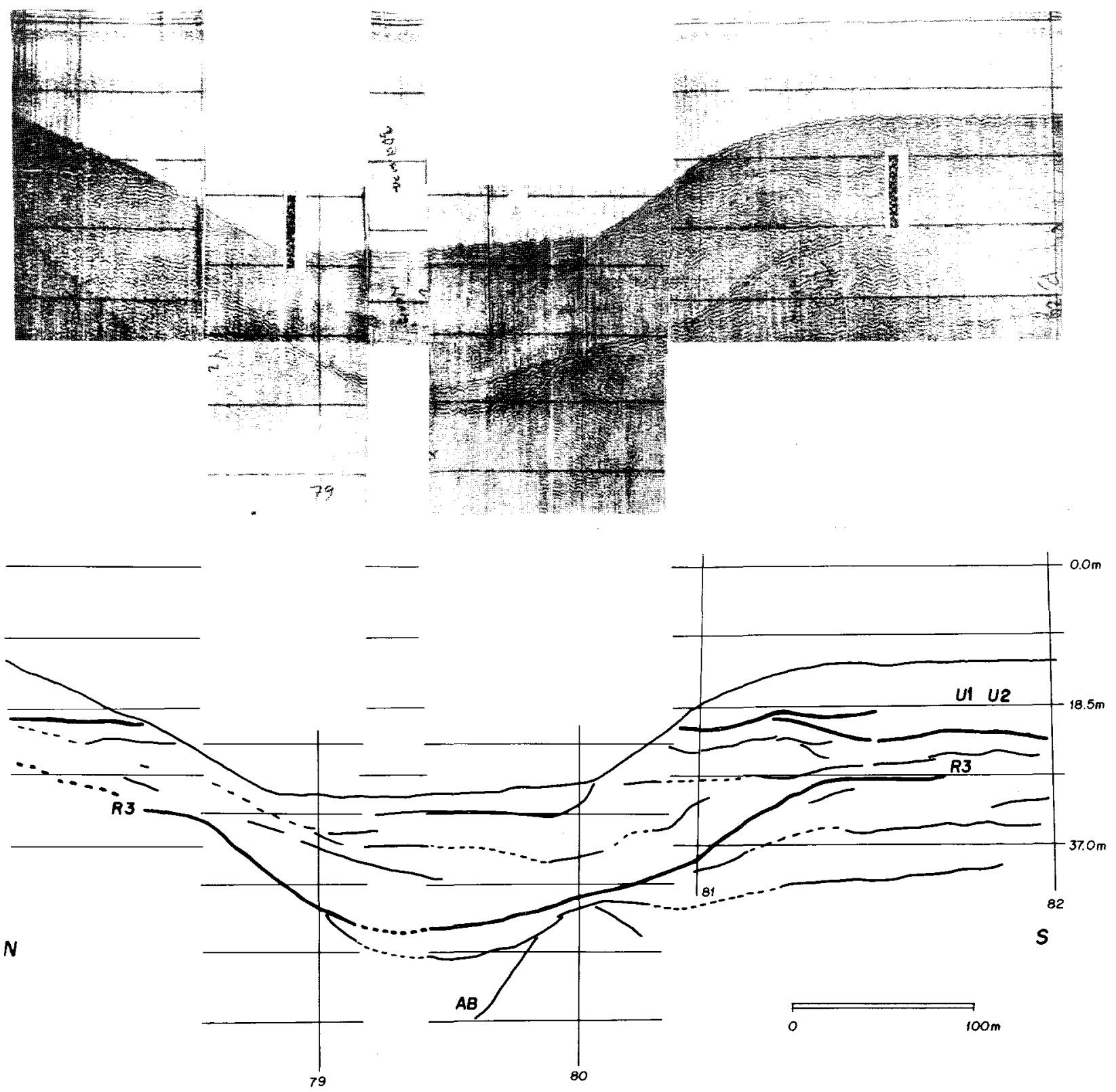

Fig. 4. a) Seismic line across Boqueirão da Tha Anchieta Strait and, b) Interpretation showing truncation of the upper reflectors. 

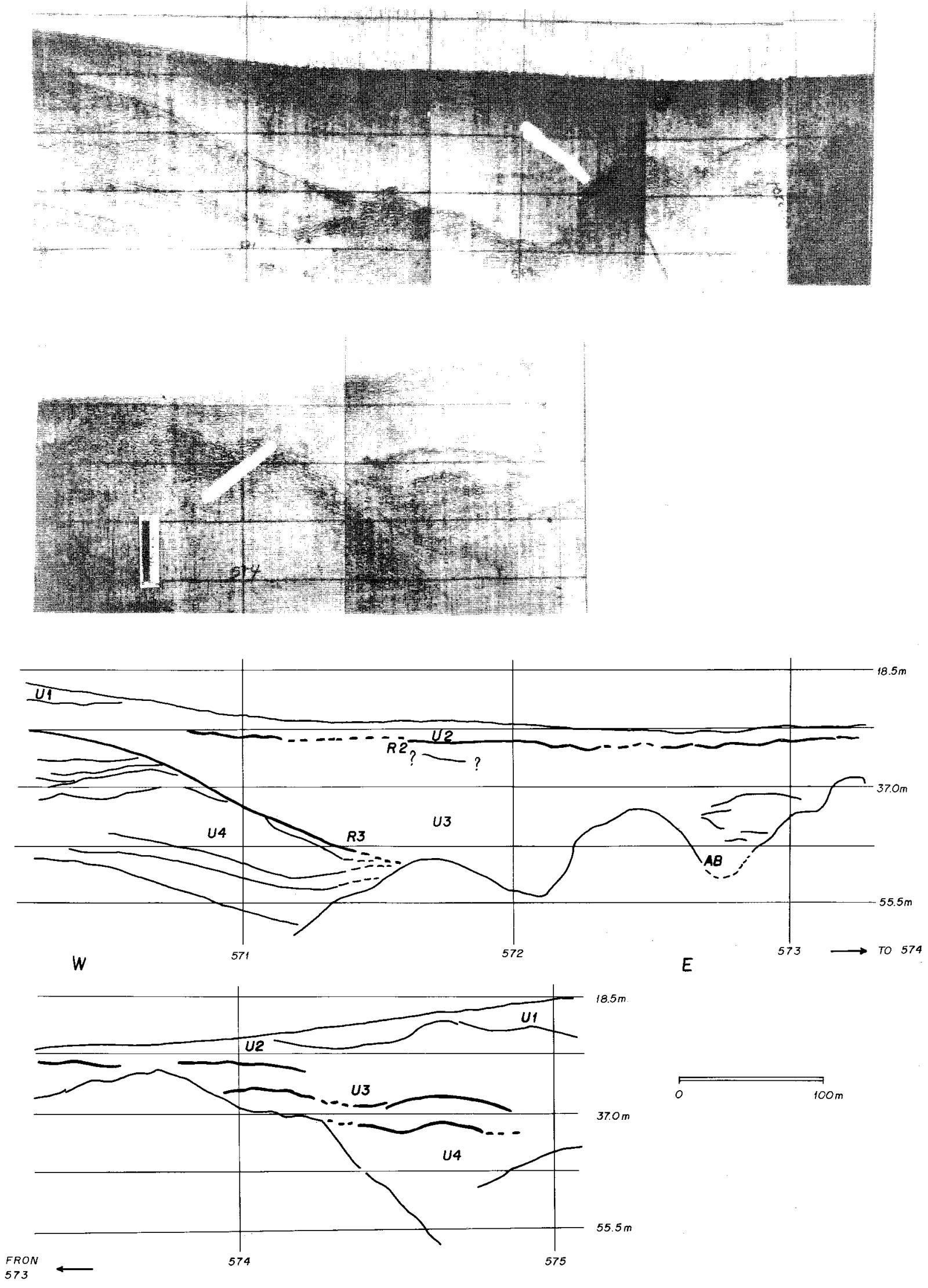

Fig. 5. a) Sismic line along Boqueirão da Ilha Anchieta Strait and, b) Interpretation showing the truncation of the deeper reflectors. 


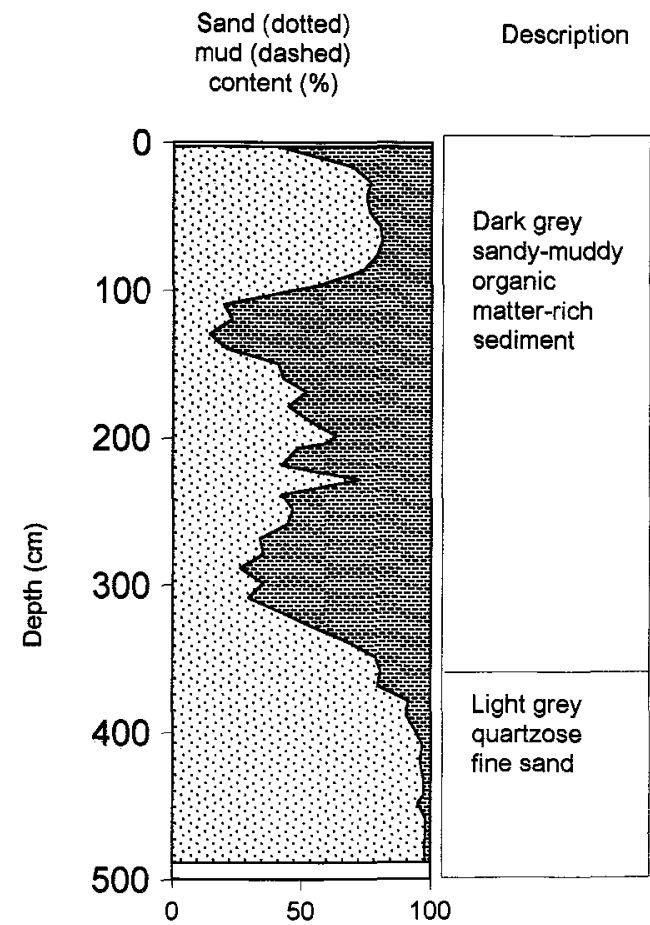

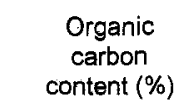

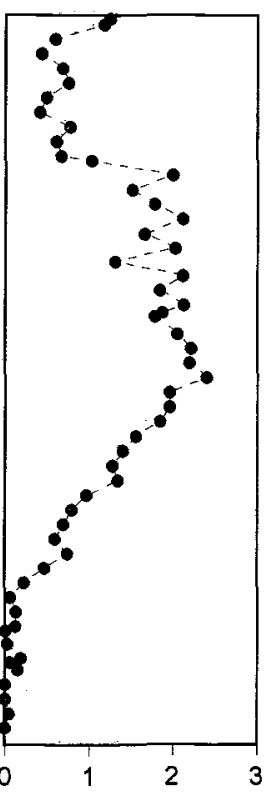

Calcium

carbonate

content (\%)

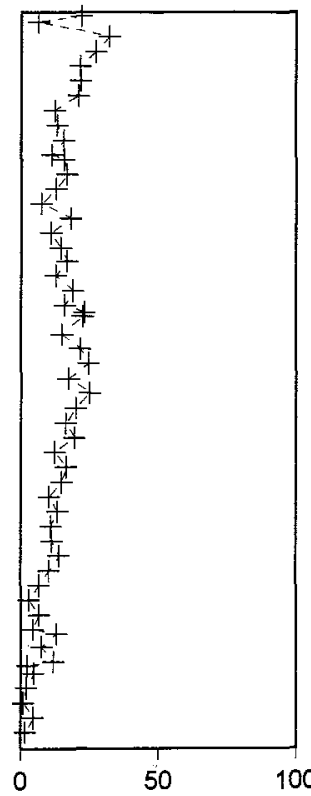

C14 ages

$5,850+-60$ y. B.P.

$6,230+-50$ y. B.P.

$7,470+-60$ y. B.P.

$8,260+-60$ y. B.P.

$7,680+-100$ y. B.P.

Fig. 6. Lithological description, sedimentological and ${ }^{14} \mathrm{C}$ age data from the core collected in the northwestern part of Flamengo bay.

The sequence of Quaternary events and their correlation with seismic reflectors and units is summarized in Table 1.

\section{Conclusions}

In the northern coastal region of São Paulo State, Brazil, four seismic units can be recognised.
The uppermost two units (U1 and U2) are correlated to the upper Holocene and uppermost Pleistocene deposits identified worldwide. Part of the upper sediments are correlated to the submergence Phase I, described for Rio Doce deposits. The deposition of Holocene marine sediments in the area started ca. 7,500 yr. BP

Table 1. Sequence of Quaternary events and their correlation with seismic reflectors and units identified in the area.

\begin{tabular}{|c|c|c|c|c|c|c|}
\hline REFLECTOR & $\begin{array}{c}\text { SEISMIC } \\
\text { UNIT }\end{array}$ & INTERPRETATION & $\begin{array}{l}\text { ISOTOPIC } \\
\text { STAGE }\end{array}$ & $\begin{array}{c}\text { AGE } \\
\text { (YEARS B.P.) }\end{array}$ & INDICATION & CORRELATION \\
\hline \multirow[t]{2}{*}{ Present surface } & & $\begin{array}{l}\text { Erosional in the flanks of } \\
\text { Boqueirão Strait, } \\
\text { depositional in Flamengo } \\
\text { and Palmas bays }\end{array}$ & & Present & $\begin{array}{l}\text { Bathimetry and } \\
\text { seismic. }\end{array}$ & \\
\hline & U1 & $\begin{array}{l}\text { High stand, shallow marine } \\
\text { deposits. Basal sediments } \\
\text { correspond to a } \\
\text { transgressive phase. }\end{array}$ & 1 & $\begin{array}{c}\text { From } 7,500 \text { to } \\
\text { present }\end{array}$ & Seisnic and core data & $\begin{array}{c}\text { Doninguez \& } \\
\text { Wanless (1991); Saito } \\
\text { (1989); Bodur \& } \\
\text { Ergin (1992); Marsset } \\
\text { et al. (1996) } \\
\end{array}$ \\
\hline \multirow[t]{2}{*}{ R1 } & & $\begin{array}{l}\text { Transgressive Holocene } \\
\text { surface }\end{array}$ & & $\begin{array}{l}\text { Between } 7,500 \\
\text { and } 5,500\end{array}$ & Core data & \\
\hline & U2 & $\begin{array}{c}\text { Alluvial to coastal deposits } \\
\text { (low stand to transgressive } \\
\text { deposits) }\end{array}$ & $2,3,4$ & $\begin{array}{l}\text { ca } 120,000 \text { to } \\
7,5000\end{array}$ & Seismic data. & $\begin{array}{c}\text { Saito (1989); Bodur \& } \\
\text { Ergin (1992); Marsset } \\
\text { et al. (1996) }\end{array}$ \\
\hline \multirow[t]{2}{*}{ R2 } & & $\begin{array}{l}\text { Sea-level maximum } \\
\text { lowering (erosive) }\end{array}$ & & Post 120,000 & Seismic data & $\begin{array}{l}\text { Inman (1983); } \\
\text { Johnson (1983); } \\
\text { Giresse (1989) }\end{array}$ \\
\hline & U3 & $\begin{array}{l}\text { Shallow marine to coastal } \\
\text { (Cananéia Transgression) } \\
\text { to alluvial deposits. }\end{array}$ & 5 & $\sim 120,000$ & & $\begin{array}{l}\text { Suguio \& Martin } \\
\text { (1978) }\end{array}$ \\
\hline \multirow[t]{2}{*}{$\mathrm{R} 3$} & & $\begin{array}{l}\text { Transgressive upper } \\
\text { Pleistocene surface }\end{array}$ & & Before 120,000 & Seismic data & \\
\hline & $\mathrm{U} 4$ & Transgressive deposits & & & Seismic data & Long et al. (1989) \\
\hline R4 and older & & & & & & \\
\hline
\end{tabular}


The base of Unit 2, corresponding to Reflector R2, represents the surface generated during the sea-level regression, corresponding to the WürmWisconsin glacial event.

Two scour events, identified in the seismic records in the Boqueirão area, are associated with high sea level phases, identified with the Cananéia and Santos sea level rise events.

Finally, at least one sedimentary sequence, which can be correlated to older Pleistocene events that have not been described before in the area, has been identified.

\section{Acknowledgements}

We wish to thank to Dr. Alberto Garcia Figueiredo Jr. of the LAGEMAR of the Universidade Federal Fluminense and Drs Moysés Gonsalez Tessler and Silvia Helena de Mello e Souza of the Instituto Oceanográfico da Universidade de São Paulo. To Dr. Jean-Claude Faugères from the Université de Bordeaux I, France, for the critical review. Our thanks are also due to Mr. Pierre Alexander Michaelovitch and Mrs. Marta Stefan for the illustrations and to Mr. Arthur Boorne for the revision of the text.

\section{References}

Almeida, F. F. M. 1964. Os fundamentos geológicos do relevo paulista. In: Azevedo, A. ed. Brasil, a terra e o homem. São Paulo, Companhia Editora Nacional. p.55-120.

Bodur, M. N. \& Ergin, M. 1992. Holocene sedimentation patterns and bedforms in the wavecurrent-dominated nearshore waters of eastern Mersin Bay (Eastern Mediterranean). Mar. Geol., 108(1):73-93.

Dominguez, J. M. L. \& Wanless, H. R. 1991. Facies architecture of a falling sea-level strandplain, Doce River coast, Brazil. Spec. Publ. Boston, Blacknell Scientific. Publ., 14:259-281.

Duleba, W. 1993. Variações nas associações de foraminíferos ao longo da coluna sedimentar da Enseada do Flamengo, Ubatuba, SP. Dissertação de mestrado. Universidade de São Paulo, Instituto Oceanográfico, $210 \mathrm{p}$.

Giresse, P. 1989. Quaternary sea-level changes on the Atlantic coast of Africa. In: Tooley, M. J. \& Shennan, I. eds. Sea-level changes. Oxford, Basil Blackwell. p. 249-275.
Inman, D. L. 1983. Application of coastal dynamics to the reconstruction of paleocoastlines in the Vicinity of La Jolla, California. In: Masters, P. M. \& Fleming, N. C. eds. Quaternary coastlines and marine archaeology: towards the prehistory of land bridges and continental shelves. London, Academic Press. p. 1-49.

Johnson, D. L. 1983. The California continental borderland: landbridges, watergaps and biotic dispersals. In: Masters, P. M. \& Fleming, N. C. eds Quaternary coastlines and marine archaeology: towards the prehistory of land bridges and continental shelves. London, Academic Press. p. 481-527.

Kowsmann, R. O. \& Costa, M. P. de A. 1974. Paleolinhas de costa na plataforma continental das regiões sul e norte brasileiras. Revta bras. Geociênc., 4(4):215:222.

Kowsmann, R. O. \& Costa, M. P. de A. 1979. Evidence of late quaternary sea level stillstands on the Upper Brazilian continental margin: a synthesis. In: INTERNATIONAL SYMPOSIUM ON COASTAL EVOLUTION DURING THE QUATERNARY. São Paulo, 1978. Proceedings. São Paulo, INQUA. p.170-192.

Magliocca, A. \& Kutner, A. S. 1965. Sedimentos de fundo da Enseada do Flamengo. Contrções Inst. oceanogr. Univ. S Paulo, sér. Oceanogr. fís., (8):115.

Mahiques, M. M. 1992. Variações temporais na sedimentação quaternária dos embaiamentos da região de Ubatuba, Estado de São Paulo. Tese de doutorado, Universidade de São Paulo, Instituto Oceanográfico. $2 \mathrm{v}$.

Mahiques, M. M. 1995. Sedimentação atual nos embaiamentos da região de Ubatuba, Estado de São Paulo. Bolm Inst. oceanogr., S Paulo, 43(2):111122.

Marsset, T.; Xia, D.; Berne, S.; Liu, Z.; Bourillet, J. F. \& Wang, K. 1996. Stratigraphy and sedimentary environments during the Late Quaternary, in the eastern Bohai Sea (North China Platform). Mar. Geol., 135(1-4):97-114.

Martin, L.; Flexor, J. M; Blitskow, D. \& Suguio, K. 1985. Geoid change indications along the Brazilian coast during the last 7,000 years. In: CORAL REEF CONGRESS, 5. Tahiti, 1985. Proceedings. Tahiti, INQUA. p.85-90. 
Ronen, A. 1983. Late quaternary sea levels inferred from coastal stratigraphy and archeology in Israel. In: Masters, P. M. \& Fleming, N. C. eds Quaternary coastlines and marine archaeology: towards the prehistory of land bridges and continental shelves. London, Academic Press. p. 121-134.

Saito, Y. 1989. Late Pleistocene coastal sediments, drainage patterns and sand ridge systemson the shelf off Sendai, Northeast Japan. Mar. Geol., 89(3/4):229-244.

SICCT - Secretaria da Indústria, Comércio, Ciência e Tecnologia. 1981. Mapa geológico do Estado de São Paulo. São Paulo, SICCT/PRÓMINÉRIO/PROMOCET. 2 v.

Suguio, K. \& Martin, L. 1979. Formações quaternárias marinhas do litoral paulista e sul-fluminense. In: INTERNATIONAL SYMPOSIUM ON COASTAL EVOLUTION IN THE QUATERNARY. São Paulo, 1978. Spec. Publ. São Paulo, INQUA. 55p.
Suguio, K.; Cruz, O.; Muehe, D. \& Amador, E. S. 1982. Coastline of the states of Rio de Janeiro and São Paulo. Rio de Janeiro, Comission on the Coastal Environment. CCE Field Trip - 8/915/1982. 50p.

Tessler, M. G. 1988. Dinâmica sedimentar quaternária no litoral sul paulista. Tese de doutorado. Universidade de São Paulo, Instituto de Geociências. 276p.

(Manuscript received 26 March 1998; revised 19 June 1998; accepted 23 March 1999) 